\title{
THE STABILIZING EFFECT OF MAGNETIC FIELD FOR THE SHAPE OF YEAST CELLS SACCHAROMYCES CEREVISIAE ON SILICON SURFACE
}

\author{
O.I. Nizhelska ${ }^{1}$, L.V. Marynchenko ${ }^{2 *}$, V.A. Makara ${ }^{3}$, S.M. Naumenko ${ }^{3}$, A.M. Kurylyuk ${ }^{3}$ \\ ${ }^{1}$ The Scientific and Training Center "Physical and Chemical Material Science", NAS of Ukraine, Kyiv, Ukraine \\ ${ }^{2}$ ggor Sikorsky Kyiv Polytechnic Institute, Kyiv, Ukraine \\ ${ }^{3}$ Taras Shevchenko National University of Kyiv, Ukraine \\ *Corresponding author: lolitamar@ukr.net
}

Received 03 December 2018; Accepted 18 December 2018

\begin{abstract}
Background. Development of methods of the targeted delivery of drugs in the nanocarriers with magnetic nanomaterials under the control of the magnetic field, industrial application of magnetically sensitive yeast, study of the viability and preservation of the biological activity of immobilized cells and the influence of various factors on the stabilization of these systems.

Objective. The aim of the work was to research the shape of yeast cells attached on the surface of silicon under influence of static magnetic field.

Methods. Cell suspension of 1-day's culture of Saccharomyces cerevisiae in distilled water was inflicted on the surface of monocrystalline silicon plates of different types of conductivity. The cell pictures were observed under a microscope in reflected light after free drying in the air and storage samples in different modes.

Results. The results of experiments showed that in control samples irreversible destruction of the attached cells took place after 7 days of storage. If drying of cells occurred under the influence of static magnetic field during 10-97 days, the yeast cells looked intact. Even after stopping of magnetic field action, they saved practically an unchanging shape during more than two years in the ordinary terms of storage.

Conclusions. The rational mode of stabilization for shape of yeast cells on the surface of silicon was determined due to the influence of a magnetic field by induction of $0.17 \mathrm{~T}$ without introducing additional substances. The possible mechanism of enhancement of adhesion associated with the gettering of positively charged impurities on the surface of silicon and the increase of the electric potential under the action of a magnetic field was considered. The method of stabilization of cells, which are attached to the surface of the silicon in a magnetic field, may be useful in the manufacture of biochips with immobilized cells.
\end{abstract}

Keywords: Saccharomyces cerevisiae; cells; stabilization; shape; silicon; magnetic field.

\section{Introduction}

Immobilization of microorganisms on abiotic (inorganic) surfaces is being actively explored according to the practical consequences of this process, such as the prevention of the formation of biofilms on artificial implants (prostheses), the use of immobilized cells in industrial bioreactors - for the synthesis or transformation of biologically active substances, in biosensors - for detecting and/or determining the amount of a substance, in materials for targeted drug delivery or in vivo diagnosis. One of the tasks of this research is to determine the viability and preservation of the biological activity of immobilized cells and the influence of various factors on the stabilization of these systems. In particular, the working capacity of the electrode in biosensors increases definitely in sensors with immobilized cells in comparison with enzymes [1]. Among the methods of immobilization on different carriers, the method of adsorption and covalent cross-linking (directly or using bifunctional rea- gents) became the most widely used, and one of the bases was silicon and its derivatives.

Due to biocompatibility, relative stability, drug release control, and biodegradability, porous silicone (PS), which is characterized by a large surface area in a small volume, can be used as a container for delivery of drugs or microdoses of specific substances [2].

Due to its optical biosensor properties, PS can be used to detect immunoglobulin $\mathrm{G}$ (IgG) in serum or whole blood [3] to diagnose tumor growth, that secrete substances which alter the reflection [4]. A free PS-based detector for detecting bacteria has also been reported [5]. Convenient and interesting to use fluorescence properties of PS (instead of fluorescent labels) is the ability to change the wavelength of the emitted light by increasing or decreasing the porosity of the material: for porosity $70-80 \%$ the sample emits green or blue light and for porosity $40 \%$ - red light. It should be noted that as biosensors with interesting optical properties are also quantum dots or inor- 
ganic nanocrystals, but unlike PS, they are toxic and therefore cannot be applied in vivo [4].

Consequently, the management (stimulation) of the immobilization of producers in industrial biotechnology and the increase of the shelf life of biochips on the basis of microorganisms as biosensors for diagnostic or analytical research is relevant.

In the research [6], an increase in adsorption of yeast cells by $140 \%$ was achieved in relation to control using polyethyleneimine solution, which is explained by the high density of its positive charge, which blocks the electrostatic repulsion of electronegative surfaces of cells and carriers.

In another study [7] yeast cell immobilization using coordination attachment of cells with silica gel by activated transition metal salts is considered. Implanted metal ions are capable of changing the value, and sometimes a sign of charge of the surface, which provides electrostatic attraction of cells. The carrier was microporous materials, granules, porous glass, ceramics. In order to illustrate the concept of the use of transition metals as the basis for the immobilization of yeast and bacterial cells, was proposed a titanium base for such biocatalysts with the possibility of commercial application in the food industry [8].

To immobilize living cells for biotechnological purposes it is desirable to exclude or minimize their contact with foreign substances. Immobilized yeast cells on chitosan particles using a magnetic field (MF) may be biocatalysts and/or bio-sorbents. In [9], the method of microwave synthesis of microparticles of magnetic chitosan has been demonstrated. The interaction of these particles with whole cells of $S$. cerevisiae leads to the formation of magnetically sensitive biocomponents. Magnetically modified yeast is easy to control with the help of an external MF, therefore the idea of the effect of the magnetic field is used for increasing the productivity of biotechnological processes in various variants, but the adhesion and adsorption of cells on magnetic particles are considered, mainly for intensifying the mass transfer using external MF [10, 11]. However, there are no reports on the industrial application of such yeast according to the number of difficulties, including technical ones, concerning the design and management of such a magnetic system.

On the other hand, the use of porous material as a carrier would create additional difficulties regarding the available surface of immobilized cells and pore size of porous material for penetration of different substrates. Therefore, it is noted that the use of non-porous magnetic materials can be more convenient and efficient [13].
Monocrystalline silicon is a nonmetal with diamagnetic properties, a semiconductor, whose properties also depend on micro-impurities. As shown in $[14,15]$, the effect of a static MF with an induction $B=0.15-0.20 \mathrm{~T}$ on monocrystalline silicon of different types of conductivity changes the properties of the surface, such as: the amount of relative microhardness of silicon decreases, the surface electric potential (which is determined by the charge states of defects on the surface) increases significantly, impurity ions migrate from the volume of samples of silicon to the surface due to the intensification of interactions between defects, which leads to new chemisorption bonds. By the combination of these effects, we can talk about the activation of the surface of silicon using MF.

The more pronounced effects of MF appear on the ferromagnetic bases - they form dendritic structures which increase the surface area [16].

External MF can affect the activity of enzymes [17], biosynthesis and yeast metabolism [18, 19] and the rate of cell reparation after lesions [20]. It is assumed that the MF affects the permeability of the cell membrane, the active transfer through the cell membrane and the synthesis of the protein. The action of external MF can also lead to the fact that some important structures in the cell will shift from their normal position that in turn affects the normal cellular metabolism.

The influence of MF on the form (contraction) of yeast cells has been documented, and the mechanism of this phenomenon is proposed [21]. Unlike electric fields, MF act only on the moving charges. The observed change of shape may be due to Lorentz's contractile force acting on diamagnetic shielding currents. This indicates an extremely high intracellular charge movement. The yeast cells are negatively charged, and this difference between the internal and external environment is supported by cell membranes. Any currents, parallel to the membrane, will experience the Lorentz contractile force, which counteracts the increase of the magnetic flux through the cell's body. The influence of MF on the spatial orientation of viral particles [22] is also established.

According to the methods of the targeted delivery of drugs in the containers with magnetic nanomaterials under the control of the magnetic field, as well as the presence of bacteria with biogenic magnetic properties in the human body [23, 24], it is expedient to study changes of the adhesive properties and morphology of microorganisms under the influence of magnetic field. 
The studies were aimed at investigating changes in the form of native (unmodified) microorganisms by using the microscopic method on the model of yeast Saccharomyces cerevisiae deposited on the surface of an inorganic carrier - monocrystalline silicon, under conditions of the influence of magnetic field and during subsequent storage.

\section{Materials and methods}

For establishment of the influence of magnetic field (MF) the samples for investigating were prepared without the using of any chemical clamps for cells on a silicon plate.

The "Lviv bakery pressed yeast" productions of JSC "Enzyme" were used as an inoculate for growing of culture. The culture of yeasts $S$. cerevisiae grew on sterile malt wort in a thermostat at $+30^{\circ} \mathrm{C}$ during $24 \mathrm{~h}$. After that the cells were filtered and a suspension was prepared in the distilled water with the concentration of order $10^{6}$ cells $/ \mathrm{cm}^{3}$.

After mixing a drop of $50 \mathrm{mcm}^{3}$ of cell suspension was inflicted on a polished fat-free surface of silicon plate. The monocrystalline silicon of p-type (furthermore - $\mathrm{p}$-Si) for solar energetic the elements and the monocrystalline silicon of n-type (furthermore $-\mathrm{n}-\mathrm{Si}$ ) for the necessities of microelectronics were used. The thickness of silicon plates was $0.36-0.50 \mathrm{~mm}$ for different samples. The Silicon oxidized on air to formation of the layer of $\mathrm{SiO}_{2}$ in thickneess of $3-5 \mathrm{~nm}$ is non-toxic material for microorganism's immobilization.

After the complete drying out of drop on air (dehydration), in 25-30 min, the surface of silicon plates was taken under a microscope in the reflected light at different magnifications.

The different modes of MF action were tested: (Mode 1) free drying out of drop of suspension on the surface of silicon with further influence of the field on a sample; (Mode 2) drying out and storage of drop of suspension on the surface of silicon in the static magnetic field; (Mode 3) the previous activation of silicon plate in the static magnetic field with the further inflicting of drop of yeasts suspension; (Mode 4) preliminary processing of a cell suspension in the modulated magnetic field with the further inflicting it on the surface of silicon.

In every series of experiments, there were simultaneously 3 control samples (with the free drying out of a drop of suspension on the initial unactivated plate of silicon without of the MF action) and experience samples. The plates of silicon were placed in static MF, the lines of magnetic induction of that are oriented perpendicular to the surface of the sample, induction $B=0.17 \mathrm{~T}$. The term of the samples treatment in static MF was from 1 to 120 days. The term of the samples treatment in the modulated electromagnetic field with frequency $50 \mathrm{~Hz}$ with induction $B=0.33 \mathrm{~T}$ was $1 \mathrm{~h}$.

The structures formed on the surface of silicon were investigated on the Carl Zeiss AXIO Observer A1M microscope. Experimental data were obtained as digital images. For the smallest increase $(\times 50)$, photographs of the general distribution of cells on the surface were obtained within the limits of the driedup drop. For an increase $(\times 100)$ and $(\times 200)$, the entire area was surveyed and determined types of cell clusters (dense solid monolayer heaps, chains, separate groups of several joined cells, single cells). The characteristic clusters of yeast for this sample were photographed no less than 10 times with magnification $(\times 1000)$, which made it possible to determine the size and shape of cells. Comparisons of images were performed visually. In order to determine changes in the sample over time, clusters of cells on the surface of silicon were photographed in a few days and months. All samples with attached cells were stored in the same conditions: at room temperature, pressure, humidity in plastic bags for protection against dust.

\section{Results}

Photos taken at different magnifications of a drop of a dried suspension under different modes of processing MF under a microscope in reflected light are shown in Figs. 1-7.

According to the best maintenance of structure of yeasts, attached on the silicon surface under MF action (Mode 2), further supervisions were conducted exactly on such conditions (Figs. 8, 9).

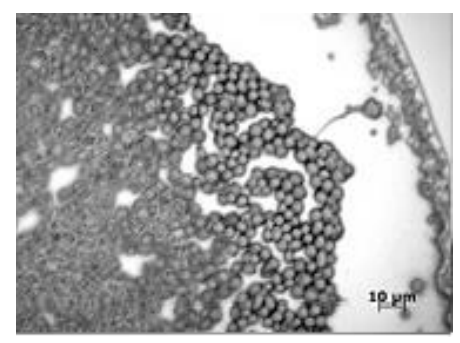

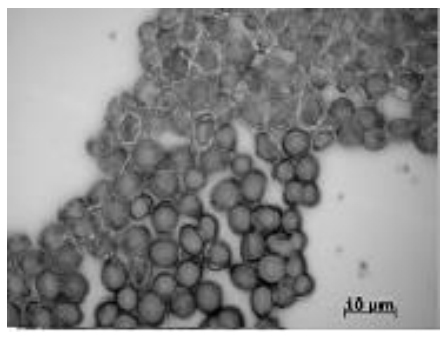

b

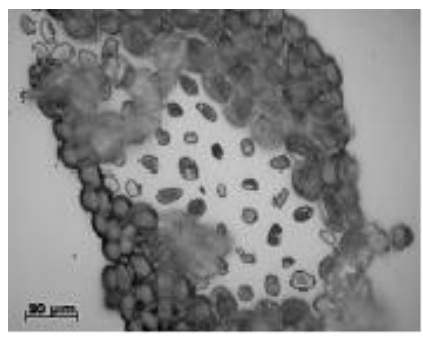

Figure 1: The yeast cells micrographs on the p-Si surface (control samples): (a), (b) 25 min drying of suspension; (c) after 7 days drying 

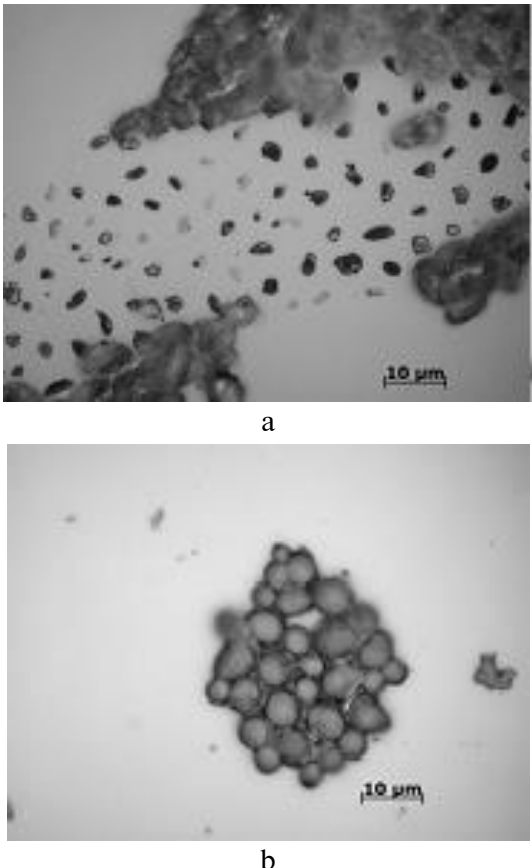

Figure 2: The weak stabilizing effect of magnetic field for the shape of yeast cells Saccharomyces cerevisiae on the p-Si surface: (a) the micrograph of the control sample; (b) the micrograph of the sample at induction MF $B=0.17 \mathrm{~T}$ for 10 days on dried yeast (Mode 1)
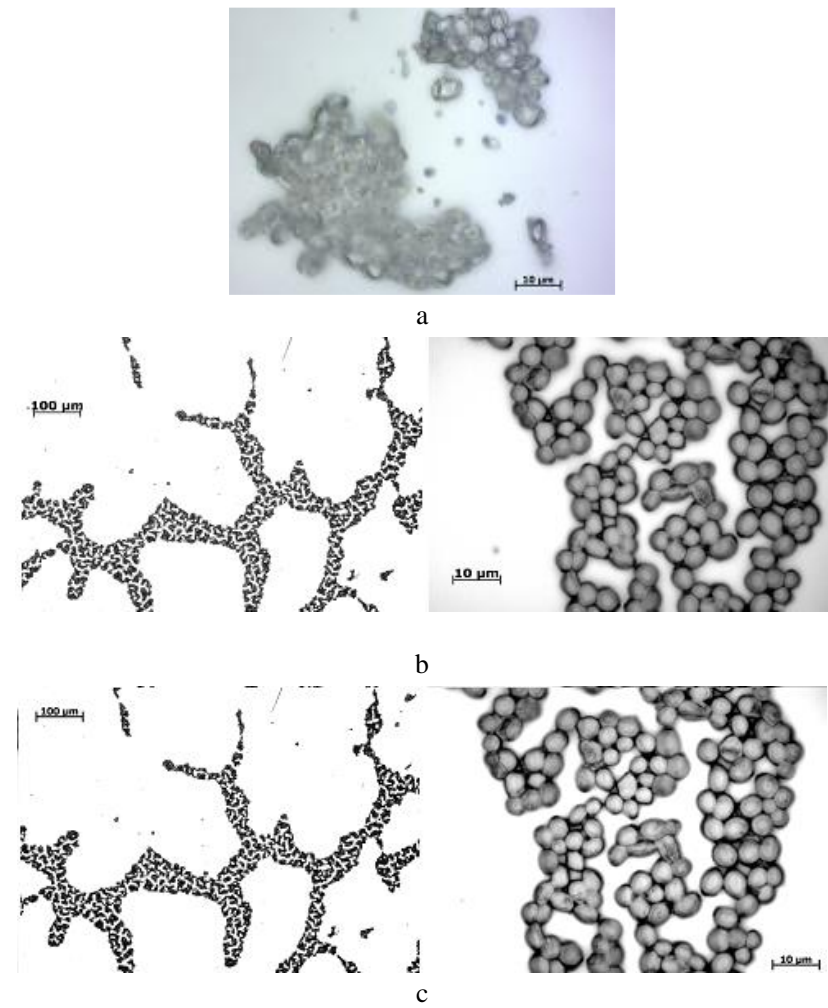

$\mathrm{b}$

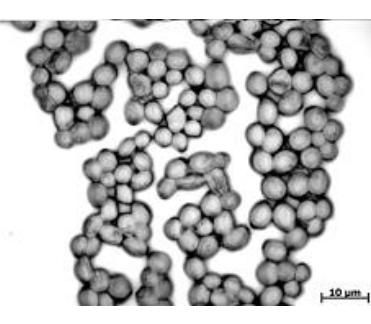

Figure 4: The stabilizing effect of magnetic field for the shape of yeast cells Saccharomyces cerevisiae on the p-Si: (a) the micrograph of the control sample; (b) the micrographs of the sample at induction MF $B=0.17$ T for 75 days drying (Mode 2); (c) the micrographs of the same sample after 2 years of storage

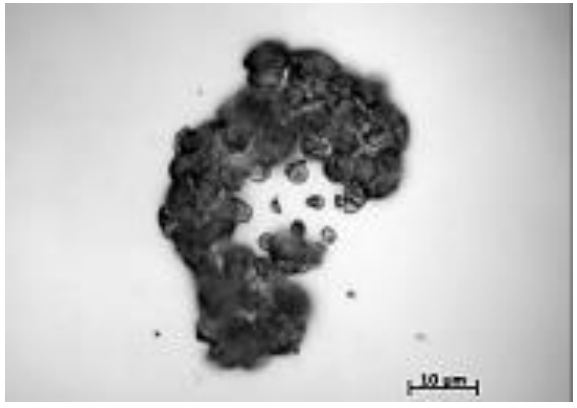

a

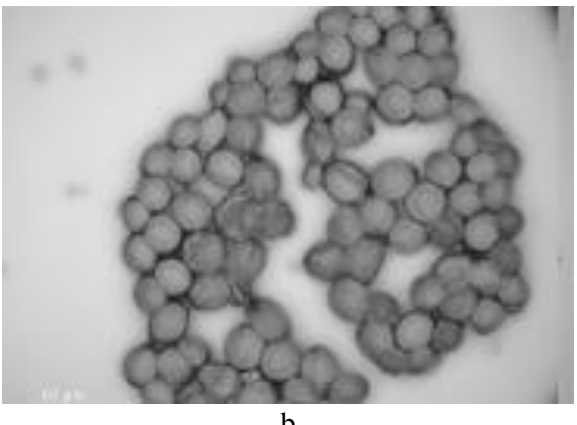

Figure 3: The stabilizing effect of magnetic field for the shape of yeast cells Saccharomyces cerevisiae on the p-Si: (a) the micrograph of the control sample; (b) the micrograph of the sample at induction MF $B=0.17 \mathrm{~T}$ during drying out and for 10 days storage (Mode 2)
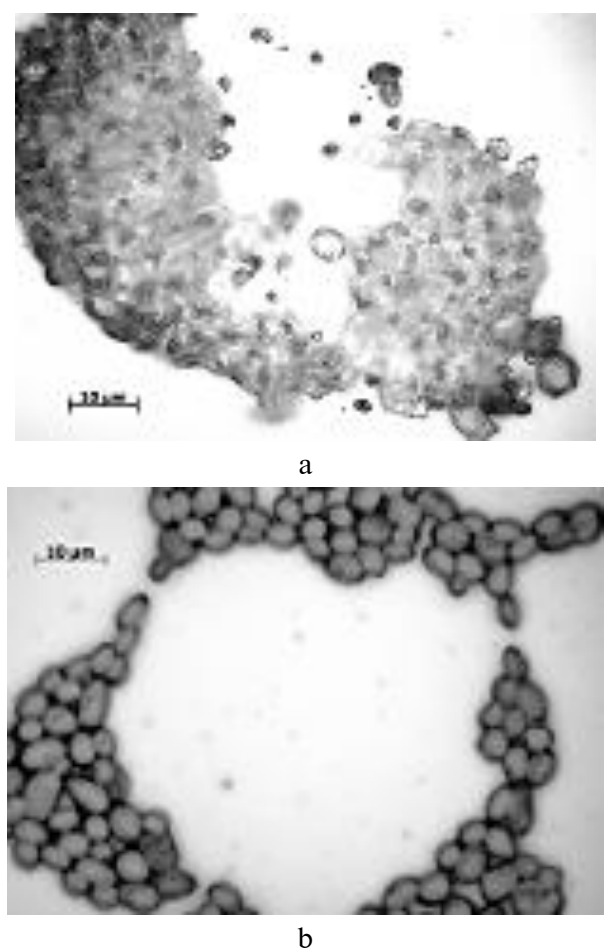

Figure 5: The stabilizing effect of magnetic field for the shape of yeast cells Saccharomyces cerevisiae on the $\mathrm{n}-\mathrm{Si}$ : (a) the micrograph of the control sample; (b) the micrograph of the sample at induction MF $B=0.17 \mathrm{~T}$ for 120 days drying (Mode 2) 

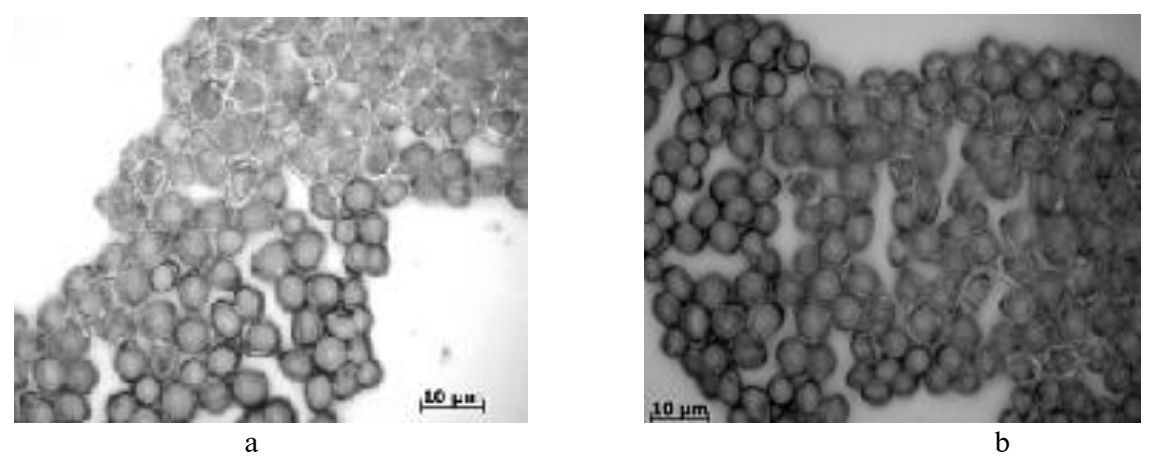

Figure 6: The weak stabilizing effect of magnetic field for the shape of yeast cells Saccharomyces cerevisiae on the p-Si: (a) the micrograph of the control sample; (b) the micrograph of the sample at previous induction MF $B=0.17 \mathrm{~T}$ for 7 days on silicon plate and 25 min drying of drop without MF (Mode 3)

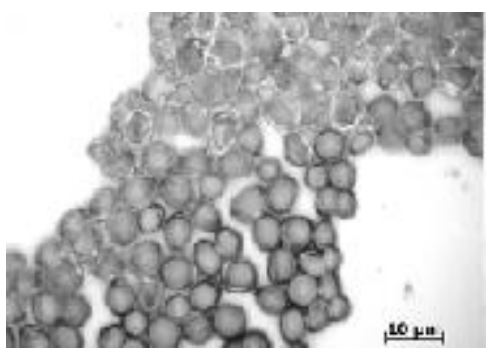

a

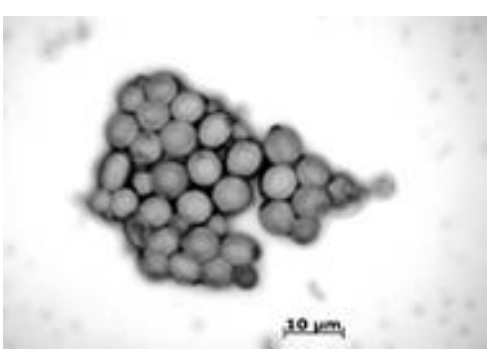

$\mathrm{b}$

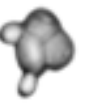

$10 \mathrm{~nm}$

Figure 7: The stabilizing effect of magnetic field for the shape of yeast cells Saccharomyces cerevisiae on the p-Si: (a) the micrograph of the control sample; (b) the micrograph of the sample at previous exposure of yeast suspension at modulated magnetic field with induction $B=0.33 \mathrm{~T}$ during 1 hour with further deposition of the drop on the surface of silicon and 25 min drying of drop without MF (Mode 4); (c) the cells in process of budding in Mode 4

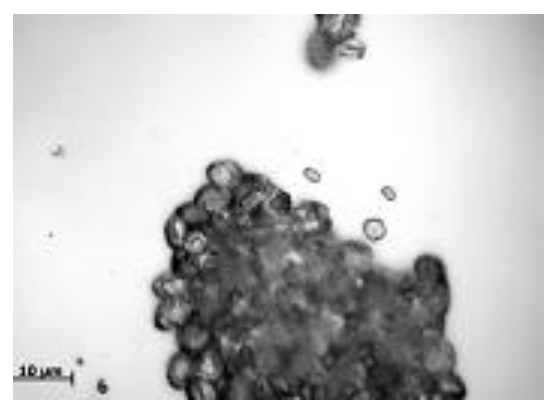

a

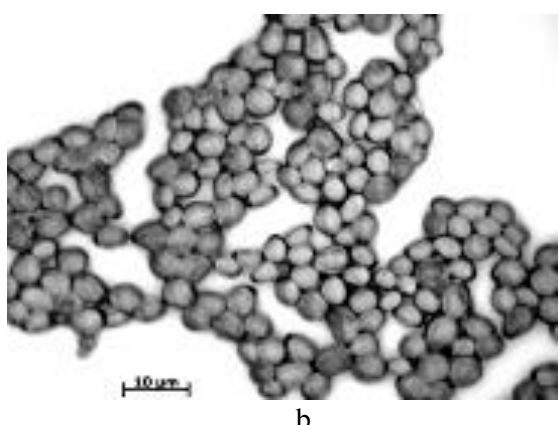

b

Figure 8: The stabilizing effect of magnetic field for the shape of yeast cells Saccharomyces cerevisiae on the p-Si: (a) the micrograph of the control sample; (b) the micrograph of the sample at induction MF $B=0.17 \mathrm{~T}$ for 97 days drying (Mode 2)

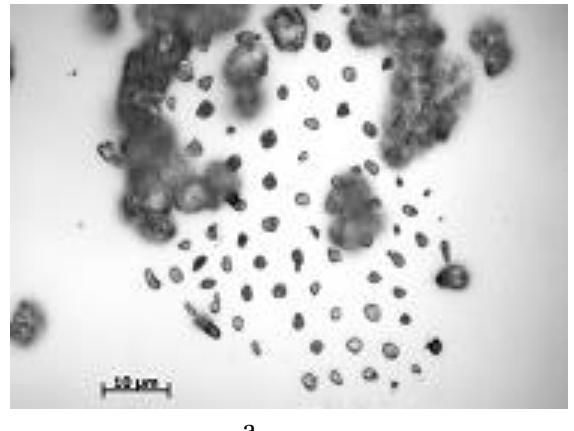

a

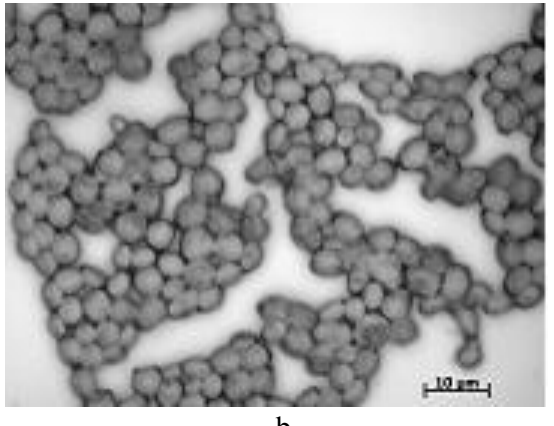

b

Figure 9: The stabilizing effect of magnetic field for the shape of yeast cells Saccharomyces cerevisiae on the p-Si: (a) the micrograph of the control sample after 162-day storage; (b) the micrograph of the sample at induction MF $\mathrm{B}=0.17 \mathrm{~T}$ for 97 days drying (Mode 2) and subsequently storage for 65 days without MF 


\section{Discussion}

The arbitrary drying of a drop of suspension cells occurred within 25-30 mins, as usual, from the periphery. The evaporation is determined by the diffusion of water vapor into the air and the characteristic feature of this process is the formation of clear boundary of phase separation ring-shaped sediment from the particles at the edge of the drop. This process was described by many researchers and is called "coffee rings" or "effect of coffee rings" [25]. Its essence is the presence of capillary flows from the middle of the droplet to its periphery, which is accompanied by the transfer of the particles of sol in the disperse system.

In our experiments, the dependence of the cell structure after drying can be traced to their location: at the edges of the drop, the cells have a clearly rounded shape, and in the central region they are mostly "blurred" or absent at all (Figs. 1(a), (c), 2(a), 4(a), 5(a), 9(a)). Consequently, we can conclude that the form was preserved better in those cells that dried up faster (for arbitrary drying).

However, the appearance of dried cells after 7 days of storage significantly deteriorated, cells were more ruined than those that were photographed immediately after drying (Figs. 1(a), (c), 2(a)). Inside the cluster of cells, their membranes were absent; only the concentrated dried remains were on the site of the cells. In control samples during 75, 120, and 162 days of drying (Figs. 4(a), 5(a), 9(a)), the tendency of greater destruction of the structure that dried up more slowly (within the cluster) was confirmed.

Under the influence of MF, the visual picture of the shape preservation of yeast cells has changed, and depending on the conditions of treatment.

The structure of cells was preserved the best in simultaneous drying of a suspension drop and MF action by induction of $0.17 \mathrm{~T}$ (Mode 2) (Figs. 3(b), 4(b), 5(b)) [26] and in the case of pretreatment of yeast suspension for 1 hour in a modulated MF $0.33 \mathrm{~T}$, followed by applying a drop to the surface of silicon and drying (mode 4) (Fig. 7(b)). It should be noted that in Mode 4 yeast even began the process of budding (Fig. 7(c)).

In the case of pretreatment of the MF of the silicon surface with subsequent application and drying of the suspension drop (Mode 3) (Fig. 6(b)), the shape of cells after 7 days remained slightly better than control but significantly worse than the 2 and 4 variants of the experiment.
If the dried sample was placed in the MF immediately after drying (Mode 1) (Fig. 2(b)), the structure of the yeast cells was partially preserved.

The positive effect of MF with an induction $0.17 \mathrm{~T}$ on maintaining the structure of yeast cells of the sample dried and stored on the surface of silicon by the influence of MF was confirmed for a longer observation during 97 and 120 days (Figs. 8(b), 5(b)). The appearance of cells did not change even after storage for 65 days already outside the influence of the MF (Fig. 9(b)), which may indicate that the processes that caused the fixation of cellular forms have already occurred.

According to the insignificant effect of the prior activation of the silicon surface (Mode 3) (Fig. 6(b)) and the absence of a difference in the silicon material ( $\mathrm{n}$ - or p-type conductivity) (Fig. 5(b)), the cause of the preservation of the shape of the yeast cells for the action of MF should be sought due to the effect of MF on the yeast cell in the aqueous medium or in surface phenomena, which occur on the plate.

It has previously been shown that the surface of monocrystalline 'solar' silicon can be modified by the influence of MF with an induction $B=0.17 \mathrm{~T}$ during 10 days.

The analysis of experimental data obtained by the method of the secondary ion mass spectrometry showed that immediately after the completion of the magnetic treatment the concentration of alkali metal ions $\left(\mathrm{K}^{+}, \mathrm{Na}^{+}, \mathrm{Ca}^{2+}\right)$, aluminum ions $\left(\mathrm{Al}^{3+}\right)$ and hydro active complexes $\mathrm{SiOH}^{+}$in the near-surface layers of "solar" silicon was exceeded 2-4 times (the Table). This is the result of an intensification of the processes of adsorption of impurities on the surface from the medium and of the processes of gettering by impurities of the surface from the crystal volume. Interestingly, according to experimental data, the electric potential of the surface of the "solar" silicon $(\mathrm{p}-\mathrm{Si})$, recorded immediately after the completion of treatment with MF, was $U=2.5 \mathrm{mV}$, and the electric potential of silicon surface with n-type of conductivity was $U=1.2 \mathrm{mV}$. However, the relaxation processes for surfaces with n-type conductivity, by contrast, lasted longer. The authors explain these effects by increasing the adsorption processes on the surface of $\mathrm{n}-\mathrm{Si}$, which, in addition to neutralizing the charges, contribute to the creation of new donor and acceptor centers $[14,15]$. 
Table: Increase of ion emission from the surface of $\mathrm{p}$-Si under the influence of the magnetic field $[14,15]$

\begin{tabular}{|c|c|}
\hline Ions & Increasing of ion emission \\
\hline $\mathrm{Na}^{+}$ & 3.76 \\
\hline $\mathrm{Al}^{+}$ & 4.18 \\
\hline $\mathrm{Ca}^{+}$ & 2.86 \\
\hline $\mathrm{K}^{+}$ & 2.24 \\
\hline $\mathrm{SiOH}^{+}$ & 3.82 \\
\hline
\end{tabular}

Consequently, given the negative superficial electrokinetic potential of the vast majority of microorganisms, in particular baker's yeast, it can be predicted that on the surface of silicon during the influence of MF are formed a positive charges that contribute to the organization of new chemosorption bonds with yeast cells. We also note that the structures formed after the colloidal solution dry up may be due to the interaction of electrical charges of yeast cells and the surface of monocrystalline silicon, which was also shown earlier by other researchers [27].

On the other hand, in the research [28], which demonstrated a change in the angle of contact and the shape of the droplet in an external electric field, it was concluded that the electric field also affects the rate of evaporation during drying. Thus, we can explain the positive results in preserving the shape of cells in terms of better conditions for drying samples during effect of MF. In other words, in the case of gettering of the surface by different charged particles, the reduction of the angle of contact contributed to the accelerated drying at the same temperature. In addition, in the case of the Mode 2, MF continued to operate longer than in Mode 3, which resulted in a better effect on the preservation of the shape of cells.

Consequently, the activation of the surface of silicon took place in the case of simultaneous drying and MF action; the formation of a positive charge was observed, which was determined by the charge state of defects on the surface (impurity ions migrated from the volume of silicon samples to the surface and were engaged with the environment), that is, attaching of cells on the plate was increased. After drying, the cells were firmly fixed to the surface and not shaken in case of plate rotation; instead of a drop, a specific composition from cells attached to a polished light-reflected plate was formed.

We also observed activation of cell proliferation after the action of the MF for 1 hour in Mode 4 before drying the suspension on the silicon surface. There was also a positive effect on the preservation of cell structures.

In the research [29] it is stated that in a modulated MF, the cell membrane undergoes deformations caused by field-induced surface charges on both sides of the membrane, and the interaction of these charges with the induced electric field creates a radial pressure on the membrane. It is also obvious that in the state of budding process, the cell wall is getting thinner. This means that drying is accelerated, which helps preserve the structure.

Also, among the mechanisms that promote the stabilization of cells in MF, it is necessary to consider the paramagnetic properties of yeast: in the MF, the movement of the cell content in the direction of the field occurs.

\section{Conclusions}

The stabilizing influence of MF for the shape of yeast cells Saccharomyces cerevisiae on silicon surface was established.

It has been found that yeast cells dried up at the influence of MF with induction $B=0.17 \mathrm{~T}$ kept the shape for a long time (up to 2 years), in contrast to the control, which was destroyed for a week. Also, the stabilizing effect of MF for the shape of yeast cells did not depend on the type of conductivity of the silicon material ( $\mathrm{n}-\mathrm{Si}$ or $\mathrm{p}-\mathrm{Si}$ ). The best effect was found in the case of simultaneous MF-treatment of silicon carrier and yeast cells suspension deposited on it when the magnetic field acts during suspension drying. Under the influence of a static MF, positive charges on the surface of silicon arise due to the migration of the impurities present in the sample, which leads to the formation of bonds with the surface of the cells and the stabilization of their form. Positive effect of MF may also be caused by deformation (getting thinner) of the cell wall.

The method of stabilization of cells, which are attached to the surface of the silicon in a magnetic field, may be useful in the manufacture of biochips with immobilized cells. Further research should include the study of the viability of such cells.

\section{Acknowledgment}

The authors are grateful to prof. G.S. Litvinov for helpful discussion and his editorial notes. 


\section{References}

[1] Gui Q, Lawson T, Shan S, Yan L, Liu Y. The application of whole cell-based biosensors for use in environmental analysis and inmedical diagnostics. Sensors. 2017;17(7):1623. DOI: 10.3390/s17071623

[2] Anglin EJ, Cheng L, Freeman WR, Sailor MJ. Porous silicon in drug delivery devices and materials. Adv Drug Deliv Rev. 2008;60(11):1266-77. DOI: 10.1016/j.addr.2008.03.017

[3] Bonanno LM, de Louise LA, Whole blood optical biosensor. Biosens Bioelectron. 2007;23(3):444-8. DOI: $10.1016 /$ j.bios.2007.05.008

[4] Ghoshal S, Mitra D, Roy S, Majumder DD. Biosensors and biochips for nanomedical applications: a review. Sensors Transducers Journal, 2010;113(2):1-17.

[5] Wu CC, Alvarez SD, Rang CU, Chao L, Sailor MJ. Label-free optical detection of bacteria on a 1-D photonic crystal of porous silicon. Proc SPIE 7167 Frontiers in Pathogen Detection from Nanosensors to Systems. 2009. DOI: 10.1117/12.809338

[6] Digel IE, Zhubanova AA. The influence of water-soluble polymers on the adhesion of cells to solid surfaces. Biotehnologiya Teoriya i Praktika. 1998;1-2:122-3.

[7] Digel IE. Effect of transition metal ions and water-soluble polymers on the attachment of yeast cells to solid surfaces [Internet]. earthpapers.net. 1998 [cited 2018 Oct]. Available from: http://earthpapers.net/vliyanie-ionov-perehodnyh-metallov-ivodorastvorimyh-polimerov-na-prikreplenie-drozhzhevyh-kletok-k-tverdym-poverhnostyam

[8] Fernandes P. Immobilization of cells with transition metal. In: Guisan JM, ed. Immobilization of enzymes and cells. 2nd ed. Humana Press; 2006. p. 367-72.

[9] Safarik I, Pospiskova K, Maderova Z, Baldikova E, Horska K, Safarikova M. Microwave-synthesized magnetic chitosan microparticles for the immobilization of yeast cells. Yeast. 2015;32(1):239-43. DOI: 10.1002/yea.3017

[10] Al-Qodah Z, Al-Shannag M, Al-Busoul M, Penchev I, Orfali W. Immobilized enzymes bioreactors utilizing a magneticfield: a review. Biochem Eng J. 2017;121(1):94-106. DOI: 10.1016/j.bej.2017.02.003

[11] Safarik I, Safarikova M. Magnetically modified microbial cells: a new type of magnetic adsorbents. China Particuol. 2007;5(12):19-25. DOI: $10.1016 /$ j.cpart.2006.12.003

[12] Robatjazi SM, Shojaosadati SA, Khalilzadeh R, Farahani EV, Balochi N. Immobilization of magnetic modified Flavobacterium ATCC 27551 using magnetic field and evaluation of the enzyme stability of immobilized bacteria. Biores Technol. 2012;104:6-11. DOI: 10.1016/j.biortech.2011.11.035

[13] Al-Hassan Z, Ivanova V, Dobreva E, Penchev I, Hristov J, Rachev R, et al. Non-porous magnetic supports for cell immobilization. J Ferment Bioeng. 1991;71(2):114-7. DOI: 10.1016/0922-338X(91)90234-8

[14] Makara VA, Steblenko LP, Korotchenkov OA, Nadtochiy AB, Kalinichenko DV, Kurilyuk AN, et al. The features of magneto-stimulating change of surface electric potential in silicon crystals used for the needs of the solar energetics and microelectronics. Nanosyst Nanomater Nanotechnol. 2014;12(2):247-58.

[15] Makara VA, Vasiliev MA, Steblenko LP, Koplak OV, Kurilyuk AN, Kobzar YuL, et al. Variations in the impurity composition and microhardness of surface layers in silicon crystals caused by a magnetic field. Semiconductors. 2008;42:1044-7. DOI: $10.1134 / \mathrm{S} 106378260809008 \mathrm{X}$

[16] Gorobets SV, Gorobets OYu, Dvoynenko OK, Lebeda GL. The effect of magnetostatic fields of ferromagnetic substrate on the nickel dendrites electrodeposition. Naukovi Visti NTUU KPI. 2011;2:143-7.

[17] Romanova ZM, Zubchenko VS, Tkachenko LV, Marynchenko LV. Effect of magnetic field on the activity of enzyme preparations [Internet]. Dspace.nuft.edu.ua. 2005 Apr [cited 2006]. Available from: http://dspace.nuft.edu.ua/jspui/bitstream/123456789/1289/1/EFFECT\%20OF\%20MAGNETIC\%20FIELD\%20ON\%20THE \%20ACTIVITY\%20OF\%20ENZYME\%20PREPARATIONS.pdf

[18] Zubchenko VS, Tkachenko LV, Protsan NV. Change alcohol yeast metabolism under magnetic field. Kharchova Promyslovist. 2009;8:22-4.

[19] Berlot T, Rehar D, Fefer M, Berovic M. The influence of treatment of Saccharomyces cerevisiae inoculum with a magnetic field on subsequent grape must fermentation. Chem Biochem Eng Q. 2013;27(4):423-9.

[20] Kotvetver VK, Korolev VG, Kutlakhmedov Yu.A., Evstikhina TA. A new type of radioprotectors based on the use of magnesium isotope magnesium-25. Naukovi Pratsi Tekhnohenna Bezpeka. 2012;185(173):54-8.

[21] Yang X, Beckwith AW, Miller JH, Wood LT. Observation of magnetic field induced contraction of fission yeast cells using optical projection microscopy. Cent Europ J Phys. 2004;2(4):636-44. DOI: 10.2478/BF02475566

[22] Litvinov GS, Polischuk VP, Boiko AL. Bacteriophage T4 structure and biological function changes under influence of constant magnetic field. Biopolym Cell. 1992;8(1):46-51. DOI: 10.7124/bc.00030E

[23] Chen C, Wang P, Li L. Applications of bacterial magnetic nanoparticles in nanobiotechnology. J Nanosci Nanotechnol. 2016;16(3):2164-71. DOI: 10.1166/jnn.2016.10954 
[24] Gorobets SV, Medviediev O, Gorobets OYu, Ivanchenko A. Biogenic magnetic nanoparticles in human organs and tissues. Prog Biophys Mol Biol. 2018;135:49-57. DOI: 10.1016/j.pbiomolbio.2018.01.010

[25] Deegan RD, Bakajin O, Dupont TF, Huber G, Nagel SR, Witten TA. Capillary flow as the cause of ring stains from dried liquid drops. Nature, 1997;389(6653):827-9. DOI: 10.1038/39827

[26] Nizhelska OI, Makara VA, Steblenko LP, Naumenko SM, Kuryluik AM, Krit OM, et al., inventors. Method of cell immobilization. Ukraine patent 120536. 2017 Nov 10.

[27] Yakhno TA, Yakhno VG. Structural evolution of drying drops of biological fluids. Tech Phys. 2009;54(8):1219-27. DOI: $10.1134 / \mathrm{S} 1063784209080210$

[28] Vancauwenberghe V, di Marco P, Brutin D. Wetting and evaporation of a sessile drop under an external electrical field: A review. Colloids Surf A Physicochem Eng Asp. 2013;432:50-6. DOI: 10.1016/j.colsurfa.2013.04.067

[29] Ye H, Curcuru A. Biomechanics of cell membrane under low-frequency time-varying magnetic field: a shell model. Med Biol Eng Comp. 2016;54(12):1871-81. DOI: 10.1007/s11517-016-1478-9

О.І. Ніжельська, Л.В. Маринченко, В.А. Макара, С.М. Науменко, А.М. Курилюк

\section{СТАБІЛІЗУЮЧИЙ ВПЛИВ МАГНІТНОГО ПОЛЯ НА ФОРМУ ДРІЖДЖОВИХ КЛІТИН SACCHAROMYCES CEREVISIAE НА КРЕМНІЄВІЙ ПОВЕРХНІ}

Проблематика. Розробка методів цільової доставки лікарських засобів у наноносіях із магнітними наноматеріалами під контролем магнітного поля, промислове застосування магніточутливих дріжджів, вивчення життєздатності та збереження біологічної активності іммобілізованих клітин і впливу різних факторів на стабілізацію цих систем.

Мета. Метою роботи було дослідження збереження форми клітин дріжджів, висушених на поверхні кремнію під впливом статичного магнітного поля.

Методика реалізації. Клітинна суспензія 1-денної культури Saccharomyces cerevisiae у дистильованій воді була нанесена на поверхню монокристалічних кремнієвих пластин різного типу провідності. Після вільного висихання на повітрі та зберігання зразків за різних режимів спостерігали зображення клітин під мікроскопом у відбитому світлі.

Результати. Результати експериментів показали, що в контрольних зразках незворотня деструкція висушених клітин відбувалась через 7 днів зберігання. Якщо висушування клітин відбувалося під впливом статичного магнітного поля протягом 10-97 днів, то клітини дріжджів видавались неушкодженими. Навіть після зупинки дії магнітного поля вони зберігали практично незмінну форму протягом більше двох років за звичайних умов зберігання.

Висновки. Визначено раціональний режим висушування дріжджових клітин на поверхні кремнію за впливу статичного магнітного поля індукцією 0,17 Тл без внесення додаткових речовин. Розглянуто можливий механізм посилення прикріплення та стабілізації форми клітин, пов'язаний із гетеруванням на поверхню кремнію позитивно заряджених домішок і зростанням електричного потенціалу під дією магнітного поля. Метод стабілізації клітин, які прикріплені до поверхні кремнію в магнітному полі, може бути корисним у виготовленні біочипів з іммобілізованими клітинами.

Ключові слова: Saccharomyces cerevisiae; клітини; стабілізація; форма; кремній; магнітне поле.

А.И. Нижельская, Л.В. Маринченко, В.А. Макара, С.М. Науменко, А.М. Курилюк

\section{СТАБИЛИЗИРУЮЩЕЕ ВЛИЯНИЕ МАГНИТНОГО ПОЛЯ НА ФОРМУ ДРОЖЖЕВЫХ КЛЕТОК SACCHAROMYCES CEREVISIAE НА КРЕМНИЕВОЙ ПОВЕРХНОСТИ}

Проблематика. Разработка методов целевой доставки лекарственных средств в наноносителях с магнитными наноматериалами под контролем магнитного поля, промышленное применение магниточувствительных дрожжей, изучение жизнеспособности и сохранности биологической активности иммобилизованных клеток и влияния различных фракторов на стабилизацию этих систем

Цель. Целью работы было исследование сохранения фрормы клеток дрожжей, высушенных на поверхности кремния под влиянием постоянного магнитного поля.

Методика реализации. Клеточная суспензия 1-дневной культуры Saccharomyces cerevisiae в дистиллированной воде была нанесена на поверхность монокристаллических кремниевых пластин разного типа проводимости. После свободного высыхания на воздухе и хранения образцов при разных режимах исследовали изображения клеток в отраженном свете.

Результаты. Результаты экспериментов показали, что в контрольных образцах необратимая деструкция высушенных клеток произошла через 7 дней хранения. Если высушивание клеток происходило под влиянием постоянного магнитного поля на протяжении 10-97 дней, то клетки дрожжей выглядели неповрежденными. Даже после прекращения действия магнитного поля они сохраняли практически неизменную форму на протяжении более двух лет при обычных условиях хранения.

Выводы. Определен рациональный режим высушивания дрожжевых клеток на поверхности кремния под влиянием постоянного магнитного поля индукцией 0,17 Тл без внесения дополнительных веществ. Рассмотрен возможный механизм усиления прикрепления и стабилизации формы клеток, связанный с геттерированием на поверхность кремния положительно заряженных примесей и увеличением электрического потенциала под действием магнитного поля. Метод стабилизации клеток, которые прикреплены к поверхности кремния в магнитном поле, может быть полезными в изготовлении биочипов с иммобилизованными клетками.

Ключевые слова: Saccharomyces cerevisiae; клетки; стабилизация; форма; кремний; магнитное поле. 